\title{
Komunikasi Harmonis Orang Tua dengan Anak
}

\author{
Anne Ratnasari \\ ABSTRACT \\ Harmony in family communication indicates the success of communication and interaction \\ exchange within family members. In this paper, a harmonious communication between parents \\ and their children was reviewed through parents credibility, the use of verbal and non-verbal \\ communication, plus parents ability to listen their children actively. By continuously added their \\ knowledge and information concerning parenting and communication, parents could increase \\ their credibility. Verbal message focused on I-message applying win-win solutions, \\ combined with humor approach, helps to delivered message effectively. Meanwhile, \\ active listening related with parents activities in giving restatement, understanding, \\ and questioning children's mind and feeling.
}

Kata kunci: komunikasi harmonis, keluarga, i-message, menyimak aktif

\section{Pendahuluan}

\subsection{Latar Belakang Masalah}

Banyak pengalaman menarik yang setiap saat dijumpai,dalam kehidupan keluarga seperti ikatan kerja sama, saling mendukung, dan menghormati di antara anggota keluarga. Hal itu dilakukan orang tua untuk mencapai tujuan berkeluarga, di antaranya bisa membesarkan anak yang bahagia, mudah beradaptasi, dan berperilaku baik. Dalam membesarkan anak, misalnya, tidak hanya menjadi tanggungjawab seorang ibu, tetapi juga keutamaan ayah sebagai mitra sejati.

Ayah dan ibu sebagai orang tua diharapkan menjadi sebuah tim yang dapat menciptakan keluarga sehat secara emosional, di mana setiap anggotanya saling menyayangi, bertanggung jawab, dan berhasil membawa mereka memeroleh kebahagiaan bersama melalui pengalaman, kasih sayang, terciptanya kehidupan keluarga yang positif, dan sebagainya. Hal ini sesuai dengan hasil penelitian Ornish, "orang yang merasa dicintai, dipedulikan, menikmati dukungan serta kedekatan, akan menjadi lebih berbahagia, dan lebih sehat."

Untuk memeroleh kebahagian tersebut, antara lain, bergantung pada keharmonisan komunikasi antaranggota keluarga: ayah, ibu, dan anak. Namun, hampir semua orang tua beranggapan bahwa mencapai keberhasilan dan kebahagiaan adalah tujuan yang sulit dicapai. Misalnya, meskipun suami istri memiliki rasa saling peduli, tidak otomatis di antara mereka saling mendukung dalam komunikasi dengan anggota keluarganya.

Salah satu masalah yang dihadapi orang tua masa kini dalam berkomunikasi dengan anak, khususnya anak remaja adalah bagaimana menumbuhkan sikap anak patuh mengikuti nasihat orang tuanya untuk mewujudkan potensi dirinya 
secara maksimal. Satu hal yang sulit ditemukan pada anak-anak di zaman sekarang. Kondisi ini terjadi bisa karena perbedaan pandangan orang tua dengan anak yang sering kali menimbulkan sikap "pertentangan", bobot pelajaran yang berat menyebabkan waktu bermain anak terbatas, orang tua sibuk bekerja, sehingga waktu bertemu dengan anak sangat sedikit, anak kurang diberi kesempatan untuk menyatakan gagasan dan pendapatnya bila terjadi suatu masalah. Bahkan, sebagai orang tua ada kalanya mengabaikan perasaan dalam berkomunikasi dengan anak. Padahal sebagai manusia, "anak-anak berhak dihormati, seperti kita ingin dihormati dan menghormati orang lain" (Hopson \& Hopson, 2002:111).

Belum lagi pengaruh nilai-nilai buruk yang diserap anak dari media, terutama televisi, yang luput dari penyaringan orang tua. Seperti orientasi nilai-nilai keberhasilan secara instan. Akibatnya, orang tua panik ketika mendapati anaknya tidak memiliki motivasi untuk berprestasi di sekolah.

Untuk memeroleh kunci sukses menjalin komunikasi harmonis dalam keluarga, tulisan ini bermaksud memberi gambaran bagaimana menyelenggarakan komunikasi harmonis orang tua dengan anak dalam keluarga ditinjau dari aspek kredibilitas orang tua, komunikasi verbal nan nonverbal, dan kemampuan orang tua mendengarkan secara aktif.

\section{Pembahasan}

\subsection{Kredibilitas Orang Tua}

Anak-anak melihat, dan cenderung meniru cara berkomunikasi orang tua dalam keluarga. Sejauhmana orang tua menerapkan aturan-aturan yang dianut dalam keluarga, misalnya, bagaimana memaknai nilai kerja keras, disiplin, jujur, tanggung jawab, dan sebagainya. Hal itu dapat terwujud bila orang tua memiliki komitmen tinggi, dan secara konsisten mengaplikasikan nilai-nilai tersebut dalam berkomunikasi dalam keluarganya.

Untuk itu orang tua perlu terus meningkatkan pengetahuan, kemampuan mereka dalam membimbing anak, Kemampuan ini berkaitan dengan kredibilitas orang tua. Kredibilitas adalah "persepsi komunikan tentang sifat-sifat komunikator, terdiri dari keahlian (antara lain berhubungan dengan kemampuan, pengalaman) dan kepercayaan (yang berkaitan dengan watak, seperti jujur, tulus, adil, dan sebagainya) (Rakhmat, 1996:257, Stiff \& Mongeau, 2003:104-105). Apabila orang tua memiliki aspek-aspek tersebut, kemungkinan anak akan menganggap orang tuanya, sebagai orang yang banyak pengetahuannya sehingga anak percaya atas apa yang disampaikannya, dan menilai orang tua sebagai orang yang konsisten mengaplikasikan nilai-nilai yang dianut keluarga.

Sebagai contoh, bagaimana keluarga mendukung keberhasilan anak dalam belajar, "bisa bercermin pada Ananda Sukarlan sebagai seorang pianis muda Indonesia yang telah mendunia, memiliki pribadi yang berhasil melihat jatidiri dan menemukan perannya dalam kehidupan secara jelas dan mantap. Ia mengatakan, "menulis karya buat saya adalah suatu tanggung jawab moral. Tekadnya adalah memajukan musik sastra Indonesia yang jauh tertinggal. Keberhasilannya merupakan perjuangan, kerja keras, dan disiplin yang berhasil ditanamkan keluarga, guru, dan dosennya."2

Pendapat senada dikemukakan Suhendi \& Wahyu (2001:75) bahwa "kemampuan orang tua bersikap konsisten, tegas, dan mampu bekerja sama", dapat menjadi teladan bagi anak dalam mengisi kehidupan. Hal itu juga merupakan upaya mempersuasi anak. Miller mendefinisikan komunikasi persuasif sebagai "pesan yang ditujukan untuk membentuk, menguatkan, atau mengubah tanggapan orang lain" (dalam Stiff \& Mongeau, 2003:4). Pendapat lain dikemukakan oleh DeVito, "dalam persuasi yang paling utama yaitu sikap, kepercayaan, dan perilaku. Dalam usaha mempersuasi, seseorang memusatkan perhatian pada upaya mengubah, memperkuat sikap atau kepercayaan khalayak, atau upaya mengajak mereka bertindak dengan cara tertentu" (DeVito,1997:447).

Berkaitan dengan perilaku, hasil penelitian Fazio \& Snyder (dalam Purnawan, 2002:22) menemukan bahwa, "perilaku seseorang 
ditentukan oleh sikapnya". Contohnya, seorang ibu memiliki sikap bahwa belajar perlu ditanamkan kepada anak sejak kecil, kemudian ia secara kontinyu menerapkan sikap tersebut dengan membimbing anaknya belajar, sehingga menyebabkan anak itu memiliki kebiasaan yang kuat untuk belajar, dan kemungkinan terus berpengaruh sampai ia dewasa.

Uraian tersebut senada dengan hasil riset Hopson \& Hopson (2002:162) bahwa, "anak tidak hanya belajar bagaimana mengatur perilaku dan emosi mereka, tetapi juga bagaimana mengatur kesehatan, rumah tangga, keuangan, dan waktu mereka". Bila orang tua menjaga kesehatan baikbaik, tidur cukup, makan dengan baik, berolah raga secara teratur, dan menerapkan pola makan yang sehat, maka anak-anak akan belajar dan menganggap semua kebiasaan yang baik itu sebagai bagian dari hidup. Dengan demikian, anak akan meniru perilaku baik yang dicontohkan orang tua.

Di sisi lain, anak juga dapat meniru perilaku buruk orang tuanya. Apabila terjadi demikian, salah satu upaya yang dapat dilakukan adalah orang tua dapat saling mendukung dan mengoreksi kebiasaan-kebiasaan buruk anggota keluarga dengan cara lemah lembut tanpa bersikap menghakimi. Bagaimana orang tua saling berinteraksi akan menjadi contoh bagi hubungan orang tua dengan anak, dan menjadi contoh yang akan diingat anak saat mereka menghadapi kesulitan.

\subsection{Pesan Verbal dan Nonverbal}

Pesan verbal ditandai dengan penyampaian "pesan aku” (I-Message), "seperti inilah perasaanku","inilah pendapatku". Juga dapat dilakukan dengan menerapkan solusi menangmenang (win-win solution), dan pesan yang mengandung humor.

Pada penerapan "pesan aku", orang tua sebaiknya terbuka mengemukakan akibat yang menimpa dirinya atas satu perilaku tertentu. Contoh: Ketika anak mengotori meja makan dan tidak merapikannya, seorang ibu dapat menyampaikan "pesan aku” seperti "Ibu kecewa, tadi pagi ibu sudah membersihkan meja makan, tapi sekarang ibu harus membersihkannya lagi”. Ketika anak mengerjakan apa yang diperintahkan orang tua, orang tua dapat segera mengucapkan pujian atas perilakunya. Karena itu akan menyenangkan anak atas usaha yang dilakukannya.

Hal ini sejalan dengan pendapat Purnawan (2002:41) bahwa, "dengan pemberian ganjaran (pay-offidea) berupa pujian (praise) dan reputasi, membuat orang merasa sangat dihargai, dan secara tidak sadar menyebabkan orang tersebut takut untuk tidak melakukan apa yang telah dipujikan kepadanya. Reputasi (cap sebagai baik), dipunyai setiap orang, dan mereka memiliki reputasinya masing-masing". Seperti, "Ibu tahu kamu memang anak yang baik ...". Pesan seperti ini tidak akan salah, karena sebagian besar anak mengikuti hati nuraninya. Teknik ini merupakan cara menggugah perhatian anak, agar mereka berempati kepada orang tua sekaligus menunjukkan penghargaan orang tua terhadap mereka.

Empati, menurut Backrack (dalam DeVito, 1997:260), adalah "kemampuan seseorang untuk mengetahui apa yang sedang dialami orang lain pada suatu saat tertentu, dari sudut pandang orang lain itu. Caranya, dengan merasakan sesuatu yang dialami orang lain seperti: menahan godaan untuk mengevaluasi, menilai, menafsirkan, dan mengkritik". Selain itu, komunikasi akan efektifbila "suasananya setara. Artinya, ada pengakuan kedua pihak sama-sama bernilai dan berharga, dan masing-masing pihak mempunyai sesuatu yang penting untuk disumbangkan" (DeVito, 1997: 261).

Apa yang terjadi jika orang tua mengucapkan kata-kata mengandung makna negatif atau menggunakan ancaman dalam berkomunikasi dengan anak. Seperti, ketika anak memeroleh nilai kecil dalam ulangan umum, Ibu berkata, "mengapa nilai kamu jelek sekali? Pasti kamu kemarin tidak belajar, dasar bodoh!", atau "kamu berkelahi lagi, ya? Anak nakal!’. Menurut Gordon, seorang ahli psikologi klinis, menyebutkan bahwa "bahasa penolakan semacam itu membuat anak yang tengah mencari jati dirinya mempercayai perkataan orang tuanya (kamu bodoh, kamu nakal), sehingga ia bertindak seperti yang dilabelkan oleh orang 
tuanya. Bahasa penolakan juga membuat anak menjadi "tertutup dan enggan berbagi cerita dengan orang lain". Mereka tidak melihat manfaat bersikap terbuka terhadap orang tua karena khawatir mendapat celaan dan kritikan. Padahal, keterbukaan anak kepada orang tua menjadi "syarat interaksi harmonis" (dalam DeVito, 1997: 260). Karena sesuai hasil penelitian, mengungkapkan perasaan "secara terbuka, jelas dan langsung, mendorong tumbuhnya dialog yang jujur, bermakna dan positif di dalam keluarga (Hopson \& Hopson, 2002: 83).

Pendapat senada disampaikan Hopson \& Hopson (2002:96) bahwa "orang tua jangan membuka diskusi dengan anak dengan memakai pernyataan negatif, seperti kita menghadapi masalah, atau bagaimana mungkin kamu bisa melakukan hal itu? Pendekatan semacam ini membuat anak tersudut, sekaligus memperuncing konfrontasi". Orang tua akan lebih efektif menerapkan metode "Saya". Misalnya, "Saya (ibu) kecewa karena kamu tidak menelepon bahwa kamu akan pulang terlambat". Dengan metode "saya", orang tua sepertinya mengakui kepemilikan perasaannya sendiri, sekaligus mengakui dan menghargai perasaan anak.

Bila orang tua berkomunikasi dengan menggunakan kata-kata yang mengandung ancaman (fear arousing) kepada anak, harus hatihati. Fear arousing yaitu "usaha memengaruhi orang lain dengan cara menakut-nakuti, atau menggambarkan konsekuensi buruk" (Rakhmat,1996:300). Hal ini karena "penggunaan ancaman akan efektif jika disampaikan dengan jelas mengenai konsekuensi yang akan diterima. Hindari memberikan ancaman yang tidak jelas, atau dengan konsekuensi yang tidak pasti. Dengan demikian, ancaman hanya diberikan jika konsekuensinya realistis dan adil, dan jika siap menjalankannya"(Lighter, 1999:51-52).

Bila terjadi perbedaan pandangan orang tua dengan anak mengenai suatu hal, misalnya seorang Ibu kebetulan melihat perilaku teman-teman anaknya yang kurang baik dan tidak dapat diterima, seyogianya Ibu tersebut melakukan apa yang disarankan Hopson \& Hopson (2002:249), yaitu, "menetapkan batasan dan larangan yang jelas kepada anak. Nyatakan ketidaksetujuan dan kekhawatiran Anda dengan jelas. Bicarakan langsung perilaku apa yang tidak dapat Anda terima dan jelaskan alasannya. Bila perlu, Anda dapat melarang mereka untuk bermain bersamasama. Bila kemudian Anda menyadari tindakan Anda berlebihan, Anda dapat menilai kembali dan melakukan negosiasi. Pastikan kepada mereka bahwa Anda menerapkan komunikasi yang terbuka dan siap kompromi."

Dawson (2002:444) mengemukakan upaya untuk mengatasinya dengan "menerapkan solusi menang-menang (win-win solution), di mana penyelesaiannya harus dapat diterima oleh kedua belah pihak". Contohnya, pada kasus orang tua merasa keberatan anaknya telat pulang sekolah, karena dia bermain dulu dengan teman-temannya. Solusi yang sebaiknya ditempuh adalah memahami perasaan anak dengan berkata, "kamu tentu lelah, sehingga tidak dapat segera mengerjakan pe-er. Atau mengekspresikan perasaan dengan mengatakan, "Ayah khawatir, jika kamu terlambat pulang sekolah". Hal lain yang dapat dilakukan dengan mengajak anak berbagi ide, seperti: "bagaimana kalau kamu bilang dulu kepada Ayah atau Ibu, akan pergi ke mana selepas pulang sekolah, agar Ayah atau Ibu tidak khawatir? Hal ini penting sekali dilakukan untuk memelihara hubungan positif antara orang tua dan anak, anak dengan temannya.

Pesan yang mengandung humor, tidak ada salahnya diterapkan dalam berkomunikasi, selama hal itu efektif. Misalnya, "anak-anak, yuk kita main air", sambil memberi contoh kepada mereka mengenai cara membersihkan lantai yang kotor. Humor bukan saja efektifmenghindarkan anak dari perasaan bersalah, tetapi juga dapat meredakan kekesalan orang tua terhadap anak.

Orang tua juga perlu melatih kemampuan komunikasi nonverbal mereka. Komunikasi nonverbal berhubungan dengan "pesan yang dikomunikasikan oleh gerakan tubuh, gerakan mata, ekspresi wajah, sosok tubuh, penggunaan jarak/ruang kecepatan dan volume bicara (DeVito, 1997:177). Selanjutnya, DeVito (1997:180) 
menjelaskan "perilaku nonverbal, apakah menggunakan tangan, mata, atau otot tubuh, biasanya terjadi dalam bentuk paket, dan seringkali perilaku seperti itu saling memperkuat, pada pokoknya mengomunikasikan makna yang sama."

Dengan demikian, orang tua perlu memberikan sentuhan penuh kasih sayang kepada anak setiap hari misalnya, baik berupa senyuman, pelukan, belaian, kecupan, tepukan, dan sebagainya. Karena curahan kasih sayang menjadi kekuatan bagi orang tua dan anak untuk saling menyesuaikan diri.

Hal lain yang juga penting adalah mencegah timbulnya konflik orang tua dengan anak. Namun, apabila terjadi demikian, orang tua harus memperhatikan, mengubah, dan menerima sikap anak sejauh sikapnya tidak menyalahi hal-hal yang prinsip. Dengan komunikasi yang dilandasi kasih sayang, orang tua lebih mudah mengarahkan sikap anak dalam mematuhi hal-hal yang bermanfaat bagi diri dan masa depannya.

\subsection{Mendengarkan Secara Aktif}

Kemampuan mendengar merupakan salah satu aspek keterampilan dasar manusia. Hasil riset Rankin \& Barker menunjukkan, "dari seluruh waktu bangun manusia sebagian besar digunakan untuk mendengarkan (53\%), selebihnya digunakan untuk membaca $(17 \%)$, berbicara $(16 \%)$, dan menulis (14\%). Artinya, manusia lebih banyak menggunakan waktunya untuk mendengarkan daripada untuk melakukan aktivitas komunikasi lainnya" ( dalam Tubbs \& Moss, 1996:158).

Meskipun banyak waktu yang dihabiskan orang tua untuk mendengarkan perkataan anaknya, ternyata tidak otomatis ia menjadi pendengar yang efektif. Seringkali ditemui keluhan antara lain mengenai kesulitan memahami pesan yang disampaikan anak akibat kekurangmampuan mendengar dengan baik.

Menjadi pendengar aktif merupakan keterampilan yang dapat dipelajari, sehingga dapat mencapai tujuan komunikasinya, yaitu "agar pendengar Anda mendengar apa yang Anda katakan (atau melihat apa yang Anda tunjukkan kepada mereka)" (Forsyth 1996:3). Unsur-unsur mendengarkan mencakup: mendengar (hearing), memperhatikan, memahami, dan mengingat. Menurut pengertiannya, mendengar adalah "proses fisiologis otomatik penerimaan rangsangan pendengaran (aural stimuli). Dalam tahap ini, gangguan fisik pada alat pendengaran seseorang dapat menimbulkan kesulitan dalam proses mendengarkan" (Tubbs \& Moss, 1996:160).

Brook berpendapat, "frekuensi bicara manusia berkisar dari 125 sampai 8000 putaran per detik, yang merupakan wilayah kritis kemampuan pendengaran. Biasanya, gelombang suara diterima oleh telinga dan merangsang impuls-impuls saraf sampai ke otak. Telinga manusia dapat mengatasi suara antara 55 sampai 85 desibel. Kecepatan katakata yang diucapkan pembicara dapat menentukan kemudahan seseorang dalam menangkap makna pesan yang diterimanya. Kecepatan rata-rata pembicara adalah antara 100 sampai 150 kata per menit. Hasil penelitian Goss menunjukkan kebanyakan orang mampu menangkap pesan yang kecepatannya 400 sampai 500 kata per menit" (dalam Tubbs \& Moss, 1996:161).

Memperhatikan. Memperhatikan rangsangan di lingkungan kita berarti memusatkan kesadaran kita pada rangsangan khusus tertentu. Memperhatikan rangsangan tertentu sambil membuang rangsangan yang lainnya disebut perhatian selektif. Mengenai perhatian orang mengenai stimuli yang diterimanya, Broadbent melakukan penelitian yang hasilnya menunjukkan, "orang cenderung memusatkan perhatian pada satu suara saja, daripada memecah-mecah perhatian dari satu suara ke suara lainnya. Hal ini karena orang lebih tertarik pada satu pesan yang berkesinambungan daripada beberapa pesan yang terputus-putus" (dalam Tubbs dan Moss, 1996:163).

Memahami. Diartikan "sebagai proses pemberian makna pada kata yang didengar, sesuai dengan makna yang dimaksud pengirim pesan. Memahami mensyaratkan pendengar untuk menghubungkan pesan dengan pengalaman di masa lalu" (dalam Tubbs dan Moss, 1996:164).

Mengingat. Yaitu, "menyimpan informasi untuk diperoleh kembali. Barker melakukan penelitian yang menunjukkan, "setelah kita 
mendengar sesuatu, kita hanya ingat separuhnya. Delapan jam kemudian kita hanya ingat 35 persen, dan dua bulan kemudian kita ingat 25 persen. Ini mengasumsikan, mula-mula kita memperhatikan pesan, dan bahwa pesan itu singkat serta relatif tidak rumit. Endapannya yang berkaitan dengan mendengarkan adalah pesan sisa, inti pesan yang diingat pendengar" (dalam Tubbs dan Moss, 1996:166).

Menurut DeVito(1997:93), mendengarkan diartikan "sebagai proses aktif menerima rangsangan (stimulus) telinga (aural). Jadi, mendengarkan merupakan proses yang aktif. Mendengar (listening) menyangkut penerimaan rangsangan dan karenanya berbeda dengan mendengar (hearing) sebagai suatu proses fisiologis. Mendengar menyangkut rangsangan aural, yaitu isyarat (gelombang suara) yang diterima oleh telinga, mencakup: isyarat verbal (kata), suara musik, suara bising, dan sebagainya". Sedangkan salah satu fungsi mendengarkan adalah untuk membantu, "bila Anda mendengarkan teman Anda mengeluh, membicarakan suatu masalah, atau berusaha mengambil keputusan, Anda melakukan mendengarkan untuk membantu" (DeVito,1997:94).

Hambatan mendengar. Dapat berupa : lingkungan fisik, saluran, dan lingkungan psikologis. Hambatan ini berkaitan dengan keadaan internal pendengar (ia sibuk dengan diri sendiri), dan masalah eksternal (sibuk dengan masalah yang berada di luar dirinya). Hambatan lain adalah hambatan yang bersifat mekanik dan semantik. Hambatan mekanik adalah "hambatan yang disebabkan oleh saluran komunikasi, sedangkan hambatan semantik, bersangkutan dengan pesan komunikasi yang pengertiannya menjadi rusak" (dalam Effendy, 1993:45). Hambatan ini dapat menjadi salah satu penyebab hambatan komunikasi antaranggota dalam keluarga, antara lain, orang tua kurang menghargai pendapat anak, padahal anak sebenarnya ingin perasaannya dipahami.

Mendengarkan secara aktif. Mendengarkan secara aktif dikembangkan oleh Thomas Gordon dalam karyanya yang disebut "P-E-T (Parent-Ef-
fectiveness-Training), yaitu proses mengirim balik kepada pembicara apa yang menurut pendengar maksudkan, baik dari segi isi maupun perasaan" (DeVito, 1997: 102). Adapun fungsinya adalah mengecek pemahaman terhadap apa yang dikatakan pembicara, dan mengutarakan penerimaannya terhadap perasaan pembicara, serta merangsang pembicara menggali perasaan dan pemikirannya.

Teknik mendengarkan secara aktif. Teknik ini meliputi: (1) mengulangi pemikiran pembicara, nyatakanlah dengan kata-kata Anda sendiri apa yang dimaksudkan pembicara. Ini akan membantu memastikan pemahaman, karena pembicara akan bisa mengoreksi pernyataan Anda. Ini juga akan menunjukkan kepada pembicara bahwa Anda berminat dengan apa yang dikatakannya. Setiap orang ingin merasa dipahami, khususnya bila sedang marah atau kecewa; (2) menyatakan pengertian terhadap perasaan pembicara, ungkapan perasaan akan memberikan kesempatan kepada pembicara untuk melihat perasaannya secara lebih obyektif. Contoh: "saya bisa membayangkan bagaimana perasaanmu. Pasti kamu merasa sangat kacau"; (3) ajukan pertanyaan untuk memastikan pemahaman Anda terhadap pikiran dan perasaan pembicara untuk mendapatkan informasi tambahan (DeVito, 1997:103). Misalnya, "bagaimana perasaanmu ketika membaca laporan penilaian karyamu?"

Menurut Hopson \& Hopson (2002:96), "bahasa tubuh bagian penting dalam komunikasi dua arah. Kontak mata langsung, duduk dengan sikap santai, mengangguk pada saat yang tepat semua perilaku tersebut memberikan kesan bahwa Anda memperhatikan perkataan lawan bicara Anda dengan pikiran terbuka". Contohnya, suatu saat seorang anak bicara dengan ekspresi sedih," Ibu, aku nggak dapat nilai seratus, gara-gara salah hitung soal nomor satu". Mendengar hal ini Ibu bisa menjawab dengan bijak, "kamu sedih ya! Kalau nilai berkurang karena ketidaktelitian kamu. Lain kali periksa lagi ya, supaya nggak terjadi lagi." Dengan mendengar aktif berarti orang tua mendengarkan kata-kata yang diucapkan anak, memperhatikan intonasinya, bahasa tubuhnya, 
juga ekspresi wajahnya, sehingga orang tua dapat menangkap isi pesan ketika anak menyampaikan isi hatinya dengan baik.

\section{Penutup}

Sebagaimana dijelaskan pada bagaian terdahulu, maka dapat dikemukakan kesimpulan sebagai berikut:

(1) Orang tua perlu memiliki komitmen tinggi dan secara konsisten mengaplikasikan nilai-nilai yang dianut keluarga dalam membimbing anaknya. Hal itu dapat terwujud bila orang tua terus meningkatkan kredibilitasnya dengan menambah pengetahuan dan kemampuannya dalam membimbing anak.

(2) Penggunaan pesan verbal ditandai dengan penyampaian "pesan aku" (I-Message), menerapkan solusi menang-menang (win-win solution), dan pesan yang mengandung humor. Orang tua juga perlu melatih kemampuan komunikasi nonverbal mereka. Memberikan sentuhan penuh kasih sayang kepada anak, karena curahan kasih sayang menjadi kekuatan bagi orang tua dan anak untuk saling menyesuaikan diri.

(3) Mendengarkan secara aktif yang dilakukan orang tua berhubungan dengan mengulangi pemikiran anak dengan cara menyatakannya melalui kata-katanya sendiri, menyatakan pengertian terhadap perasaan anak dengan memberikan kesempatan kepadanya melihat perasaannya secara lebih objektif, dan mengajukan pertanyaan untuk memastikan pemahaman orang tua terhadap pikiran dan perasaan anak untuk mendapatkan informasi tambahan.

\section{Catatan Akhir:}

${ }^{1}$ Nirmala. 2005. "Cinta Itu Menyembuhkan". 2005. Nirmala, 02/Februari Hal. 78.

${ }^{2}$ Intisari. 2007. "Di Usia Muda Mereka Harumkan Indonesia". No. 53, Oktober.

\section{Daftar Pustaka}

Stiff, James B. \& Mongeau, Paul A. 2003. Persuasive Communication. New York: The Guilford press.

Dawson, Roger.2002. Secrects of Power Negotiating: Rahasia Sukses Seorang Negosiator Ulung. Jakarta : PT. Gramedia Pustaka Utama.

DeVito, Joseph A. 1997. Komunikasi Antarmanusia, Penerjemah Agus Maulana, Jakarta: Professional Books.

Effendy, Onong Uchjana. 1993. Ilmu, Teori \& Filsafat Komunikasi. Bandung: PT. Citra Aditya Bakti.

Forsyth, Patrick. 1996. Agreed!: Negosiasi Menang-Menang dengan Komunikasi Persuasif. Jakarta: PT. Gramedia Pustaka Utama.

Hopson, Darlene Powell \& Hopson, Derek S. 2002. Menuju Keluarga Kompak: 8 Prinsip Praktis menjadi Orangtua yang Sukses. Penerj. Lala Herawati D. Bandung: Kaifa.

Intisari. 2007. "Di Usia Muda Mereka Harumkan Indonesia". No. 53, Oktober 2007.

Lighter, 1999. Menanamkan Sikap positif pada Anak. Yogyakarta: Kanisius.

Nirmala. 2005. “Cinta Itu Menyembuhkan”. 02/ Februari.

Purnawan, E.A. 2002. Dinamic Persuasion : Persuasi Efektif dengan Bahasa Hipnosis. Jakarta: PT. Gramedia Pustaka Utama.

Rakhmat, Jalaluddin. 1996. Psikologi Komunikasi. Bandung: PT Remaja Rosdakarya.

Suhendi, Hendi \& Wahyu, Ramdani. 2001.Pengantar Studi sosiologi Keluarga. Bandung: CV. Pustaka Setia.

Tubbs, Stewart L. dan Sylvia Moss.1996. Human Communication. Penerjemah Deddy Mulyana. Bandung: PT Remaja Rosdakarya. 
